\title{
The Effectiveness of Using PQ4R Method on Teaching Reading Viewed From Students' Intelligent Quotient (IQ)
}

\author{
Khumaira, Ngadiso, Sujoko \\ English Education Department \\ Teacher Training and Education Faculty \\ Sebelas Maret University of Surakarta
}

Email: khumaira108@gmail.com

\begin{abstract}
The aim of this research is to find out whether: (1) PQ4R Method is more effective than Direct Instruction Method to teach reading; (2) students who have high intelligence have better reading skill than those who have low intelligence; and (3) there is an interaction effect between teaching methods and students' intelligence in teaching reading. The research method used in this study is an experimental method. This research took 24 students for the experimental group and 24 students for the control group. The research instrument used to collect the data in this study is test. The data were analyzed by using multifactor analysis of variance $2 \times 2$ and Tuckey test. The computation of the data shows that: (1) PQ4R is more effective than Direct Instruction to teach reading; (2) the students who have high intelligence have better reading skill than those who have low intelligence; and (3) there is an interaction between teaching methods and students' intelligence in teaching reading.
\end{abstract}

Keywords: teaching method, reading skill, intelligence.

\section{INTRODUCTION}

Learning a language is expected not only to help the students realize themselves, their culture, and others but also to help them to express ideas and opinion to participate in their lives. In this global area, English is a means of communication in the daily life as both written and spoken language. It plays an important role in the communication with other people in the world.

English lesson is divided into two skills, receptive and productive skills.. Reading and listening are said to be receptive skills, while writing and speaking are said to be productive skills. This research is focused on reading skill as an essential factor to elaborate English for communication. Aebersold and Field (1997: 15) say that reading is what happens when people look at text and assign meaning to the written symbols in that text. Supporting Aebersold and Field, Wallace (1992: 3) also states that reading is interpreting, which means reacting to a written text as a piece of communication. It can be concluded that reading is an activity to interpret the meaning of the written text as a piece of communication between the reader and a text.

There are some factors which influence teaching learning process of reading. These factors can come from the students, the teacher, and the text. the next factor is the quality of the teacher or instructor. The creative teacher will use teaching method which is appropiate with the students' condition in the class and can atrract them to be more instersted in learning English especially reading skill. There are 
many teaching methods that can be applied in teaching reading. One of them is PQ4R method. PQ4R is one of the methods for comprehending reading material which was developed by Robinson in 1927. This method allows students to take their own roles in comprehending reading material. The steps are Preview, Question, Read, Reflect, Recite, and Review. This method uses student-centered classroom. This method is good enough to make the students more active in reading.

PQ4R Method can be used in teaching reading because it has many benefits, such as ithelps students with low memorization ability to memorize learning materials. PQ4R is appropiate to use in teaching declarative material like grounded concepts, definition, and applied knowledge in daily life. PQ4R will also encourages students to improve questioning skill and to communicate his or her knowledge. In addition, it can be applied easily in any education level and covers teaching materials widely.

Another common method that is usually used by teachers to teach reading is Direct Instruction Method.Direct instruction requires teachers to provide background information, to demostrate the skill being taught, and then to provide time for students to practice the skill and receive feedback on how they are doing (Arends, 1998: 428). the teacher has control over what will be learned and has control of the timing of the lesson. The weakness of this method is that the activity of this method is teacher-centered that makes the students have lack of opportunities in the class to share their own oppinions, because in teaching and learning process the students just become followers and depend on the teacher's direction.

Intelligence is another factor of learning reading which arises from the students. Deboer (1966) states that background experience, interest, and native intelligence may also play a part in determining how many and which individual words a reader may miss and still have high comprehension. It can be concluded that intelligence has a crucial role for improving students' comprehension in reading skill. There is a substansial correlation between intelligence and reading skill (Deboer, 1966).

From the explanation of some experts above, the researcher summarizes that PQ4R makes students have important role in comprehending written material or text. Students have their own opportunities to understand the text using PQ4R's steps.

Meanwhile, the teacher's role only as a guide and helper for students. Students has a big chance to create classroom atmosphere and being active during teaching learning process. PQ4R Method makes students more

enjoy the class and have more interaction with the text than Direct Instruction Method.

Aonther method that can be used to teach reading is Direct Instructional Method. In direct method the teacher has important role in teaching learning process. The teacher is the primary source of comprehensible input and as the creator of classroom atmosphere. By using this method, the students lose their opportunities in the classroom. Students become passive and have limited ways for expressing their ideas and opinions in the classroom. Then, it can be concluded that direct instructional method is a highly teacher-central method of teaching in which the teacher has big role to control the students. In this case, the students rely on teachers' direction and guidance.

Another factor which influences the students' intelligence. It is said that the students who have high level of intelligence will have high skill to comprehend the text 
and can learn more quickly rather than students who have low level of intelligence

Based on the identification above, the most important thing in teaching is that a teacher must find the better method. PQ4R and direct instructional method are two of methods that can be used to teach reading. Therefore, the writer is interested to compare the use of $\mathrm{PQ} 4 \mathrm{R}$ and direct instructional method to teach reading to the students of senior high school in order to find out which method is more effective to be applied viewed from student's IQ.

From the explanation above, the hypotheses of this research can be formulated as follows: (1) PQ4R method is more effective than Direct Instruction Method for teaching reading at the eleventh grade of senior high school; (2) Students who have high IQ have better reading skill than those who have low IQ at the the eleventh grade of senior high school; and (3) There is an interaction between teaching methods and students' intelligence on the students' reading skill at the eleventh grade of senior high school.

\section{RESEARCH METHODS}

This research was conducted at the eleventh grade of a senior high school in Surakarta. The writer took two classes as the sample. Those classes were class XI MIA 4, consisting of 24 students, as the experimental group who were taught using PQ4R Method and XI MIA 5, consisting of 24 students, as the control group who were taught using Direct Instruction Method.

The method used in this research is experimental method with pretest-posttest and control group design. According to Burke (in Cahyaningrum, 2010: 60), Experimental design with Pretest- Posttest and Control Group is a research design that administers a post-test to an experimental group and a control group after both groups have been given a pre-test and one of the groups has been administered to the experimental treatment condition. The experimental group was the group that received the experimental treatment condition, which is taught by using PQ4R Method, while the control group was the group that did not receive the experimenal treatment condition, which is taught by using Direct Instruction Method. After the treatment, the groups were given post-test. In addition, before the the treatment, the students were classified based on their intelligence: the high and low.

Before testing the hypothesis, there are two pre-requisites which are necessary must be done: normality and homogeneity test. Normality test is used to know whether the sample is in normal distribution or not while homogeneity is applied to find out whether the data are homogeneous or not. This test is important because homogeneity of the data shows that the population is wellformed. The normality testing used in this research is Liliefors testing at the level of significance of $0.05(\alpha=0.05)$, while the homogeneity testing used Bartlet formula at the level of significance of $0.05(\alpha=0.05)$. After that, the writer used multifator analysis of variance (ANOVA) $2 \times 2$ and Tuckey test to test the hypothesis.

In this research, the writer used instrument in the form of reading test to measure students' reading skill. The data which were analyzed in this research are pre-test and post-test scores of the two groups, experimental group and control group.

Statistically, hypothesis can be said as: (1) the students who are taught using PQ4R Method have better reading skill than students who are taught using Direct Instruction Method. Statistically, the hypothesis can be formulated as $\mathrm{H}_{1}: \mu \mathrm{A}_{1}>\mu$ $\mathrm{A}_{2}$; (2) students who have high intelligence 
have better reading skill than students who have low intelligence. Statistically, the hypothesis can be formulated as $\mathrm{H}_{1}: \mu \mathrm{B}_{1}>\mu$ $\mathrm{B}_{2}$; and (3) there is an interaction effect between teaching methods and students' intelligence in teaching reading skill. It means that the effect of teaching methods on the student's reading skill depends on intelligence.Statistically, the hypothesis can be formulated as $\mathrm{H}_{1}: \mu \mathrm{A} \times \mu \mathrm{B}>\mathrm{O}$.

\section{RESEARCH FINDINGS DISCUSSIONS}

AND

This research was conducted at the eighth grade students of senior high school. The experimental group, class X MIA 4, was taught using PQ4R method and the control group, class X MIA 5, was taught using direct instructional method.

The data are divided into eight groups: (1) the data of the students who are taught using PQ4R Method $\left(\mathrm{A}_{1}\right)$; (2) the data of the students who are taught using Direct Instruction Method $\left(\mathrm{A}_{2}\right)$; (3) the data of the students having high intelligence $\left(\mathrm{B}_{1}\right)$; (4) the data of the students having low intelligence $\left(\mathrm{B}_{2}\right)$; (5) the data of the students having high intelligence who are taught using PQ4R Method $\left(\mathrm{A}_{1} \mathrm{~B}_{1}\right)$; (6) the data of the students having high intelligence who are taught using Direct Instruction Method $\left(A_{1} B_{2}\right) ;(7)$ the data of the students having low intelligence who are taught using PQ4R Method $\left(\mathrm{A}_{2} \mathrm{~B}_{1}\right) ;(8)$ the data of the students having low intelligence who are taught using Direct Instruction Method $\left(\mathrm{A}_{1} \mathrm{~B}_{1}\right)$.

Before testing the hypothesis, there are two pre-requisites which are necessary must be done: normality and homogeneity test. The normality test calculation shows that the data are in normal distribution.

From the computation of homogeneity test of pre-test, it can be seen that $\chi^{2}=4.032$ is lower than $\chi_{\mathrm{t}}^{2}=7.82$ or $\chi^{2}$ $<\chi_{\mathrm{t}}^{2}$. Because $\chi^{2}$ is lower than $\chi_{\mathrm{t}}^{2}$, it can be concluded that the data are homogeneous.

After finding out the result of the prerequisite, the writer then calculated the data analysis using multifactor analysis of variance (ANOVA) 2x2. The calculation shows that $F_{0}$ between columns (4.22) is higher than $\mathrm{F}_{\mathrm{t}(0.05)}$ (4.06). $\mathrm{H}_{\mathrm{o}}$ is rejected and it means the difference between columns is significant. The students' mean of $\mathrm{A}_{1}$ (70.42) is higher than the students' mean of $\mathrm{A}_{2}$ (66.42).

$\mathrm{F}_{\mathrm{o}}$ between rows (6.38) is higher than $\mathrm{F}_{\mathrm{t}(0.05)}$ (4.06). $\mathrm{H}_{\mathrm{o}}$ is rejected and it means the difference between columns is significant. The students' mean of $\mathrm{B}_{1}$ (70.88) is higher than the students' mean of $\mathrm{B}_{2}$ (65.96).

$\mathrm{F}_{\mathrm{o}}$ interaction (22.57) is higher than $\mathrm{F}_{\mathrm{t}(0.05)}$ (4.06). $\mathrm{H}_{\mathrm{o}}$ is rejected and it can be stated that there is an interaction effect between the two variables, the teaching methods and the degree of intelligence on the reading skill.

After analyzing the data by ANOVA, the data analyzed by using Tuckey HSD test. HSD is Honestly Significant Different. Tuckey test is conducted to find out the difference between cells, means which method is more effective and which group is better.

The calculation shows that $\mathrm{q}_{\mathrm{o}}$ between columns (2.906) is higher than $q_{t(0.05)} \quad$ (2.86), the difference between columns is significant. The students' mean of $A_{1}$ (70.42) is higher than the students' mean of $A_{2}$ (66.42). $q_{o}$ between rows (3.574) is higher than $\mathrm{q}_{\mathrm{t}(0.05)}$ (2.86). The student's mean of $\mathrm{B}_{1}(70.88)$ is higher than that of $\mathrm{B}_{2}(65.96)$.

$q_{o}$ between cells $\left(A_{1} B_{1}\right.$ and $\left.A_{2} B_{1}\right)$ (9.626) is higher than $\mathrm{q}_{t(0.05)}$ (2.95). The mean score of students having high intelligence taught using PQ4R Method $A_{1} B_{1}$ (77.5) is higher than that of those who 
have low intelligence taught using Direct Instruction Method $\mathrm{A}_{2} \mathrm{~B}_{2}$ (64.25).

$\mathrm{q}_{\mathrm{o}}$ between two cells $\left(\mathrm{A}_{1} \mathrm{~B}_{2}\right.$ and

$\left.\mathrm{A}_{2} \mathrm{~B}_{2}\right)(3,814)$ is higher than $\mathrm{q}_{\mathrm{t}(0.05)}(2.95)$, The mean score of students having low intelligence who are taught by Direct Instruction (68.58) is higher than that of those who are taught by using PQ4R (63.33).

Referring to the result of Tuckey test at points 3 and 4 above, it can be inferred that PQ4R is more appropriate method for the students with high intelligence, while direct instruction is appropriate method for students with low intelligence in teaching reading. Hence, it can be summarized that there is an interaction between teaching methods and the students' intelligence in teaching reading.

The result of the research shows that the students who are taught using PQ4R Method have better reading skill than students who are taught using Direct Instruction Method, the students who have high intelligence have better reading skill than students who have low intelligence and there is an interaction effect between teaching methods and students' intelligence in teaching reading skill. It means that the effect of teaching methods on the student's reading skill depends on intelligence.

PQ4R is one of the effective method in reading skill. This method can help the teacher in teaching learning process, and it can help the students to understand of the text so that they can explore their knowledge. PQ4R method is efficient method to facilitated comprehending of texts that they read (Pehofer and Roy, 2003: 42)

All activities in this method are students-centered. Meanwhile, the teacher's role is only as a guide and helper for students. Students have a big chance to create classroom atmosphere and be active during teaching learning process. PQ4R method can stimulate students to be active in getting information of a subject. It means that in this method, students have important role to be active in teaching and learning process (Rathus, 2006: 32). PQ4R Method makes students enjoy the class more and have more interaction with the text than Direct Instruction Method.

On the contrary, Direct Instruction Method is a direct model of teaching in which the teacher teaches the material to the students by using English directly. English here is as prime conductor language which is used for all activities and explanations in the classroom and the teacher doesn't use mother tongue to explain the difficult words. In direct instruction method the teacher has important role in teaching learning process. In reading class, the teacher has to define the skill or content and the students practice careful through the teacher directions (Arends, 1998: 257).

The students who have high level of intelligence will acquire knowledge quickly and apply the knowledge effectively. The students having high intelligence have high ability in comprehending a text. The students with high intelligence are active, creative, and have good participation in learning process because they have effective adaptation to real world environments (Stenberg, 1985: 45). Students with high intelligence give more argumentation and opinion during the teaching and learning process that makes the situation in the classroom more interesting. It can be concluded that there is substansial correlation between intelligence and reading skill. The students having high intelligence will have better reading skill than those having low intelligence.

On the other hand, students with low intelligence will find the difficulty in acquiring new knowledge. They usually do not have any interest and motivation in 
joining the learning process. They are passive because they prefer becoming listeners and following participants in learning process. It proves they are slower in doing reading tasks which are given to them as stated by Deboer (1960: 132) the students who have low intelligence will have low ability in understanding a text. It happens because they have less capacity to learn and to solve the problem, and to carry on abstract thinking. That's the reason why the students' having high intelligence have better reading skill than those having low intelligence.

Students' participation in learning activities is strongly affected by teaching methods. PQ4R method is students-centered beacuse it makes students more active, interactive, and creative. This method improves students' memorization in undertsanding text substantially that supports readers for gaining information deeply and widely, so it can improve the comprehension of a subject matter. It is also statedby Jim and Pratt (2009: 134) that PQ4R is good method to comprehend information of text and it can also stimulate knowledge.

The students having high intelligence are more active high-motivated, and creative to get involved in learning. In reading they are easy to understand the text and to gain information deeply. They can do undertanding the texts effectively and no more time-consuming. This may cause the students with high intelligence achievement will be better than those lower ones. Rahmi (2011: 157) state that high intelligence especially considered to be the most relevant one to reading skill.

In PQ4R method students are able to gain information from the text more. The six steps of this method stimulates students to be active in getting information of the text. It helps students memorize a lot of information from the text. Based the explanation above, it can be concluded that cooperative reading groups is more effective to teach reading for students having high intelligence.

Meanwhile, direct instruction method is the tecaher-centered which focuses on information transfer. It emphasizes on the teacher's role in presenting information by talking to the students. In direct instruction method teacher explains a new concept or skill to a large group of students, having them test their understanding by practicing under teacher direction (that is, controlled practice), and encouraging them to practice under teacher guidance (Joyce, Weil, and Calhoun, 1986: 339).

On the other hand, students having low intelligence tend to wait for some instruction from the teacher on what to do in the class. They often have difficulties in putting their thoughts in tight words. They have lack of working memory especially in memorizing and remembering information deeply. Bakken and Mastrioperi (1997) as cited in Worth (2005: 30) state that low intelligence students with poor comprehension evidenced difficulty with main idea formulation, memory of details, and inferencing when reading.

Direct instruction method seems satisfy the students having low intelligence. It can be concluded that direct instruction method is more effective to teach reading for the students having low intelligence.

Based on the explanation above, it can be concluded that there is an interaction between teaching methods and the students' intelligence for teaching reading. The effect of teaching method used depends on the level of the students' intelligence. 


\section{CONCLUSIONS AND SUGGESTIONS}

The result of the research show that PQ4R Method is better than Direct Instruction Method to teach reading, so, the writer draws some conclusions as follows:

(1) PQ4R is more effective than Direct Instruction Method to teach reading to eleventh grade students of senior high school; (2) the students who have high intelligence have better reading skill than those who have low intelligence of the eleventh grade students of senior high school; and (3) there is an interaction between the teaching method and intelligence in teaching reading to the eleventh grade students of senior high school.

Having concluded the result of the research, the writer would like to propose some suggestion. For English teachers, teachers are suggested to apply PQ4R

\section{BIBLIOGRAPHY}

Aebersold, Jo Ann. Field, Mary Lee. 1997. From Reader to Reading Teacher: Issues and Strategies for Second Language Classrooms. Cambridge: Cambridge University Press

Arends, R.I. 1998. Resource Handbook.

Learning to Teach (4 $4^{\text {eed. }}$.). Boston, MA: Mc Graw-Hill.

Cahyaningrum, Dewi. 2010. The effectiveness of using video in teaching listening of oral narrative text. Unpublished Thesis. Sebelas Maret University of Surakarta
Method in teaching reading in order that that students' skill in reading can improve. To English students, they should be active in the teaching learning process. For students who have low intelligence they must be aware of the importance of active involvement in teaching and learning process and their teacher is not only source in learning, then they have to encourage themselves. Besides, they must try to practice to improve their reading skill.To other researchers, the writer hopes that this method can be applied in the other skills, such as listening, speaking, reading, and writing and in other level of students. Considering that this research still has weaknesses, the writer hopes that the other researchers can use the result of this research as the references for further research.

Jim and Jane Pratt. 2009. Turtle On A Fence Post. Canada: Agio.

Pehofer, Johan and Roy William. 2003. New Media and Teacher Education. New York: ITE Conference.

Rathus, Spencer A. 2006. Childhood and Adolencence. Canada: Thomson Wadsworth.

Sternberg, R. J. (1985): Beyond IQ: A triarchic theory of human intelligence. New York: Cambridge University Press.

Wallace, Chatherine. 1992. Reading. Oxford: Oxford University Press. 